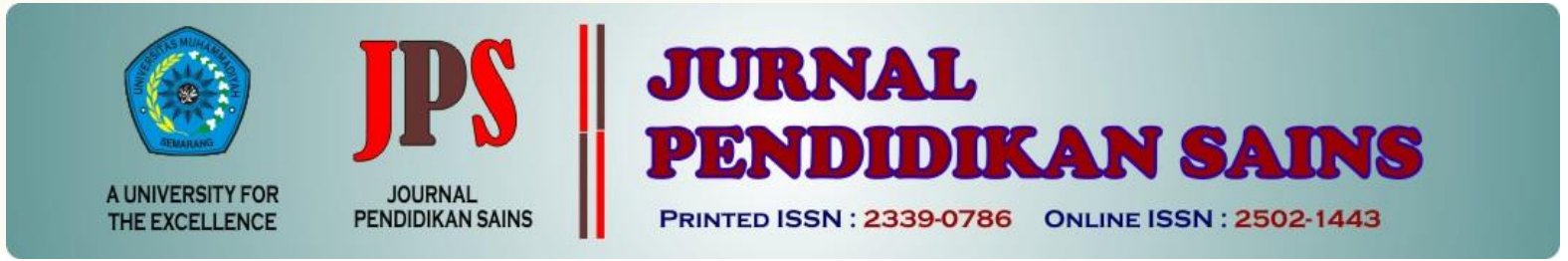

http://jurnal.unimus.ac.id/index.php/JPKIMIA

\title{
METODE FIELD TRIP UNTUK MENINGKATKAN KEMAMPUAN PEMAHAMAN KONSEP FISIKA DAN MENGAKSES KETERAMPILAN PROSES SAINS
}

\author{
Oleh: Mujib Ubaidillah \\ Tadris Biologi IAIN Syekh Nurjati Cirebon
}

\begin{tabular}{l}
\hline Article history \\
\hline Submission : 2018-03-08 \\
Revised $\quad: 2018-03-28$ \\
Accepted $\quad: 2018-03-29$
\end{tabular}

Abstract

Tujuan penelitian ini untuk meningkatkan kemampuan pemahaman konsep fisika dan mengakses keterampilan proses sains mahasiswa tadris biologi melalui metode field trip. Metode penelitian menggunakan eksperimen quasi dengan pretest-postest control group. Teknik pengambilan sampel menggunakan purposive sampling. Sampel penelitian ini mahasiswa tadris biologi A dan B semester 1 IAIN Syekh Nurjati Cirebon. Instrumen penelitian berupa soal tes dan lembar penilaian keterampilan proses sains. Hasil penelitian menunjukan bahwa kemampuan pemahaman konsep fisika mahasiswa

Keyword:

Kata kunci: field trip, kemampuan pemahaman konsep fisika, keterampilan proses sains

kelas eksperimen berbeda signifikan dengan kelas kontrol. Kemampuan pemahaman konsep kelas eksperimen lebih tinggi dari pada kemampuan keterampilan kelas kontol. Metode field trip dapat mengakses keterampilan proses sains. Keterampilan proses sains yang dapat diakses melalui field trip yaitu keterampilan dasar, keterampilan memroses dan keterampilan menginvestigasi. Keterampilan proses sains yang dominan yaitu keterampilan dasar dan keterampilan memroses.

\section{Pendahuluan}

Fisika merupakan bagian ilmu pengetahuan alam (sains). Ilmu Fisika berasal dari hasil penelitian dan kajian terhadap fenomena alam yang dilakukan oleh ilmuwan yang dilakukan melalui proses ilmiah. Proses ilmiah sendiri melibatkan observasi, pengumpulan data, analisis, dan proses verifikasi terhadap data dan gejala alam. Carin \& Sund (1990) menyatakan bahawa sains meliputi dua cakupan yaitu sains sebagai produk dan sains sebagai proses. Sejalan dengan itu, Collete \& Chiappetta (2007) mengemukakan bahwa ilmuwan dalam memperoleh pengetahuan dan produk berupa fakta, konsep, prinsip, dan teori melalui proses dan sikap ilmiah.

Tujuan pembelajaran fisika diantaranya untuk mengantarkan mahasiswa menguasi konsep-konsep fisika, dan dapat mengaitkannya sehingga dapat memecahkan permasalahan fisika dalam kehidupan sehari-hari. Menguasai konsep fisika dapat ditandai dengan menjadikan mahasiswa tidak sekedar tahu (knowing) dan hafal (memorizing) terkait konsep fisika, namun menjadikan mahasiswa mengerti dan memahami (to understand) konsep fisika dan menghubungkan keterkaitan suatu konsep dengan konsep lain (Lubis, 2009).

Pemahaman konsep merupakan suatu proses mental terjadinya adaptasi dan

*Corresponding Author:

Nama : Mujib Ubaidillah

Lembaga : Tadris Biologi FITK IAIN Syekh Nurjati Cirebon

Email : mujib@syekhnurjati.ac.id 
transformasi ilmu pengetahuan (Gardner, 1999). Anderson \& Krathwohl (2001) menyatakan bahwa kemampuan memahami (understand) dalam ranah kognitif digolongkan menjadi 7, yaitu: interpretasi (interpreting), menerangkan dengan contoh (exemplifying), mengklasifikasi (classifying), merangkum (summarizing), inferensi (inferring), membandingkan (comparing), dan eksplanasi (explanation).

Pentingnya pemahaman konsep fisika bagi mahasiswa menekankan pada bagaimana konsep fisika diperoleh mahasiswa. Perolehan konsep fisika memerlukan metode yang tepat. Penting bagi mahasiswa mengkonstruksi pengetahuan dan konsep fisika. Salah satu metode pembelajaran yang dapat membatu siswa mengkonstruksi pengetahuan mahasiswa yaitu melalui metode field trip. Suparno (2007) menyatakan bahwa belajar melalui field trip merupakan pembelajaran konstruktivisme. Pembelajaran konstruktivisme menekankan pembentukan pengetahuan mahasiswa. Pengetahuan merupakan konstruksi mahasiswa sendiri terhadap sebuah objek yang diamati.

Pentingnya pembentukan pengetahuan mahasiswa yang utuh terhadap objek yang diamatinya, maka perlu metode yang dapat menjembatani antara pengetahuan yang bersifat teori dan praktik. Amosa et.al. (2015) menyatakan bahwa field trip merupakan perjalanan kelompok dari lingkungan pendidikan formal untuk mendapatkan pengalaman langsung dari tempat yang diminati.

Marini et al., (2015) menyatakan bahwa melalui penerapan metode field trip pembelajaran sains lebih menyenangkan dan meningkatkan pemahaman siswa. Kegiatan mengamati objek secara langsung dapat meningkatkan pemahaman siswa serta efektif meningkatkan hasil belajar. Patrick et al., (2013) menyatakan bahwa field trip perlu menggabungkan keterampilan memecahkan masalah, terikat dalam kurikulum, fokus pada standar, dan mempertimbangkan kebutuhan peserta didik. Upaya menuju pembelajaran di ruang informal yang lebih efisien, maka siswa lebih banyak untuk merancang dan melaksanakan kegiatan batas secara struktural. Amosa et.al, (2015) menyatakan bahwa field trip dalam pengajaran dan pembelajaran menghasilkan pembelajaran yang efektif dan efisien. Fatkur (2013) menyatakan bahwa field trip dapat meningkatkan hasil belajar sains. Yuliati, \& Martuti (2014:185) pembelajaran menggunakan metode field trip efektif meningkatkan hasil belajar, kepedulian siswa terhadap lingkungan dan respon positif siswa. Berbeda dengan hasil penelitian Japar (2017) yang menyatakan bahwa tidak ada perbedaan hasil belajar siswa melalui field trip dengan yang tidak melakukan field trip.

Pembelajaran fisika dengan metode field trip dapat dilaksanakan dengan mengajak mahasiswa ke suatu tempat yang mengandung nilai fisika atau saintifik (Suparno, 2007). Objek field trip mengandung unsur ilmu dan wisata. Field trip dapat dilakukan dengan membawa mahasiswa ke sebuah museum sains, atau industri yang menggunakan prinsip-prinsip fisika. Mahasiswa diajak untuk mengamati fenomena alam, demonstrasi fisika, kemudian melakukan percobaan dan membuat laporan terkait hasil pengamatan.

Keunggulan metode field trip menurut Amosa, et al. (2015) yaitu mahasiswa mendapatkan pengalaman langsung pada seting alami, meningkatkan minat siswa dalam belajar untuk mengumpulkan data, materi atau objek untuk pelajaran di kelas serta untuk mengamati objek atau fenomena yang tidak mungkin dibawa masuk kelas. Omosewo (2009) menjelaskan bahwa kunjungan lapangan dapat digunakan sebagai kesempatan untuk mengumpulkan data untuk analisis selanjutnya, untuk menghasilkan karya dan merangsang diskusi baik di lokasi maupun di sekolah dan tutorial di universitas, seminar dan lokakarya.

Japar (2017:) mengungkapkan bahwa keberhasilan pembelajaran fisika menggunakan metode field trip, yaitu: memberikan waktu yang lebih banyak dalam menerapkan metode field trip pada materi yang memiliki banyak konsep, melakukan perencanaan yang matang terkait tempat field trip yang dikunjungi, dan menyesuaikan waktu pelaksanaan field trip dengan waktu pembelajaran. Pradyani et al. (2014) dan Ratnasari (2014) menyatakan bahwa pembelajaran field trip mempunyai keunggulan yaitu, dengan melihat objek langsung siswa dapat memperdalam pengetahuan, siswa dapat melihat, mendengar, meneliti, dan mencoba objek secara langsung. Mundilarto \& Suharyanto (2015) menyatakan bahwa outdor learning (field trip) dapat menumbuhkan kompetensi inti aspek spiritual, aspek pengetahuan dan sosial siswa pada mata pelajaran fisika.

Patrick (2010) pembelajaran melalui metode field trip dapat meningkatkan kemampuan aspek kognitif, psikomotorik dan 
afektif. Pembelajaran fisika melalui eksperimen dapat meningkatkan keterampilan proses sains dan keterampilan berpikir tingkat tinggi (Ubaidillah, 2016). Temuan Amosa et al. (2015) terkait field trip guru harus mengajak siswa melakukan kunjungan lapangan untuk mempromosikan dan mendorong keterlibatan aktif dalam pembelajaran, motivasi diri, belajar penemuan dan belajar dengan pengalaman.

Bryce et al. (1990) menyatakan bahwa keterampilan proses sains mencakup keterampilan dasar (basic process science skill), yang terdiri dari keterampilan dasar (basic skill) dan keterampilan memroses (process skill) dan keterampilan melakukan investigasi. Keterampilan dasar meliputi, a) keterampilan melakukan pengamatan, b) keterampilan merekam data/informasi, c) keterampilan mengikuti perintah, d) keterampilan melakukan pengukuran, e) keterampilan mengimplementasikan prosedur. Keterampilan memroses terdiri dari, a) membuat prediksi, b) membuat inferensi, c) menyeleksi prosedur. Keterampilan melakukan investigasi terdiri dari, a) keterampilan merancang investigasi, b) melaksanakan investigasi, d) melaporkan hasil investigasi.

Penelitian sebelumnya yang dilakukan oleh Yarid \& Ariswan (2016) bahwa pembelajaran field trip akan lebih berpengaruh jika aspek keterampilan proses sains diukur. Pembelajaran akan lebih bermakna apabila dalam pembelajaran aktivitas mahasiswa diukur dalam kegiatan field trip (Kisiel, 2006). Suparno (2007). Pembelajaran melalui metode field trip mengarahkan mahasiswa dalam memperoleh pendalaman konsep ilmu fisika yang terkait dan kesegaran karena berwisata (Suparno, 2007). Hal ini sejalan dengan Myers \& Linda (2012) yang menyatakan bahwa, metode field trip merupakan metode yang memberikan pengalaman unik pada mahasiswa di luar kelas, memberikan pengalaman terkait konsep dan topik yang dibahas. Hasil penelitian sebelumnya menjadi dasar peneliti melakukan penelitian untuk mengukur keterampilan proses sains dalam kegiatan field trip. Keterampilan proses sains mahasiswa penting diakses melalui kegiatan pembelajaran fisika di luar kelas. Begitu juga dengan pemahaman konsep fisika mahasiswa juga perlu ditekankan dalam proses pembelajaran di luar kelas. Pemahaman konsep dan keterampilan proses sains merupakan modal utama yang penting bagi mahasiswa dalam pembelajaran fisika. Oleh karena itu perlu dilakukan penelitian yang mengkaji tentang pembelajaran fisika dengan metode field trip untuk meningkatkan pemahaman konsep fisika dan mengakses keterampilan proses sains mahasiswa.

\section{Metode Penelitian}

Penelitian ini menggunakan metode quasi experiment dengan pretest-postest control group. Populasi penelitian merupakan mahasiswa semester 1 tahun akademik 2017/2018. Teknik pengambilan sampel menggunakan purposive sampling. Sampel penelitian mahasiswa semester 1 Tadris IPA Biologi yang terbagi dalam kelas eksperimen (2A) dan kelas kontrol (2B). Kelas eksperimen menggunakan metode field trip dan kelas kontrol menggunakan metode pembelajaran konvensional. Instrumen penelitian menggunakan instrumen tes berupa soal essay yang mengukur kemampuan pemahaman konsep fisika dan lembar penilaian keterampilan proses sains. Untuk melihat kenaikan rata-rata nilai pretes-postes menggunakan gain standar. Perhitungan gain standar mengacu pada perasamaan gain standar (Meltzer, 2002). Persamaan untuk teknik tersebut adalah sebagai berikut:

Gain standar $=\frac{\text { skror postest-skror pretest }}{\text { skror maksimum-skror pretest }}$

Keterangan:

$\mathrm{N}$-Gain $>0,70$ (tinggi), $0,30 \leq \mathrm{N}$-Gain $\leq 0,70$ (sedang), dan $\mathrm{N}$-Gain $<0,30$ (rendah).

Analisis aspek keterampilan proses sains mahasiswa menggunakan kriteria skala 4.

Tabel 1. Kriteria skala 4 Penilaian Keterampilan Proses Sains

\begin{tabular}{ccc}
\hline Rentang skor (i) & Nilai & Kriteria \\
\hline $55,25 \leq \bar{M} \leq 68$ & A & Sangat baik \\
$42,50 \leq \bar{M}<55,25$ & B & Baik \\
$29,25 \leq \bar{M}<42,50$ & C & Cukup \\
$17 \leq \bar{M}<M i-29,25$ & D & Kurang \\
\hline
\end{tabular}

(Sukardjo, 2008)

Keterangan :

$\bar{M}=$ mean (rata-rata skor ideal)

$=(1 / 2)($ skor tertinggi ideal + skor terendah ideal)

$M_{i}=$ skor aktual 
Skor tertinggi ideal $=\sum$ butir kriteria $\mathrm{x}$ skor tertinggi

Skor terendah ideal $=\sum$ butir kriteria $\mathrm{x}$ skor terendah.

\section{Hasil Penelitian dan Pembahasan}

Kegiatan pembelajaran fisika dengan metode field trip dilakukan di Taman Pintar Yogyakarta. Kegiatan field trip melibatkan guru, mahasiswa, asisten praktikum dan instruktur yang ada di Taman Pintar. Mahasiswa melakukan kegiatan eksperimen dengan dipandu oleh asisten praktikum, dosen dan instruktur. Berikut disajikan langkahlangkah kegiatan pembelajaran dengan field trip pada Tabel 2.

Tabel 2. Fase Metode Filed Trip

\begin{tabular}{|c|c|}
\hline Fase & Kegiatan \\
\hline Pre-Trip & $\begin{array}{ll} & \begin{array}{l}\text { Koordinasi antara mahasiswa } \\
\text { dan dosen }\end{array} \\
- & \text { Menetapkan lokasi field trip } \\
- & \text { Mempersiapkan administrasi, } \\
& \text { akomodasi dan instruksi } \\
- & \text { Membagi mahasiswa dalam } \\
& \text { kelompok kecil (setiap } \\
& \text { kelompok terdiri dari } 3 \\
\text { mahasiswa) } \\
-\quad & \text { Merancang kegiatan investigasi } \\
- & \text { Pengecekan kesiapan field trip } \\
- & \text { Mahasiswa mengerjakan soal } \\
\text { tes (pretest) }\end{array}$ \\
\hline Trip Stage & 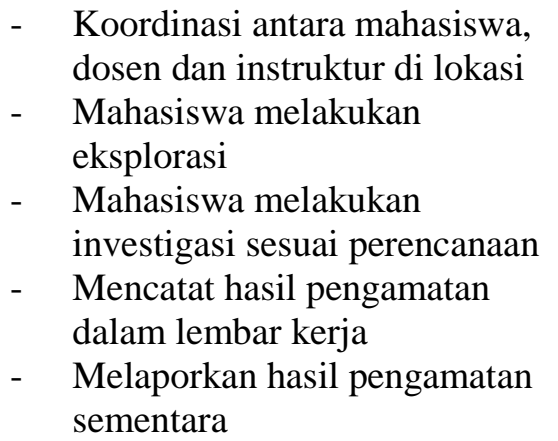 \\
\hline Post-Trip & 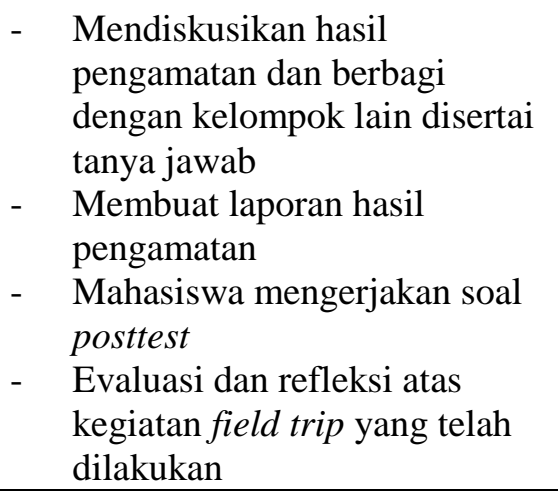 \\
\hline
\end{tabular}

(Dimodifikasi dari Myers \& Linda, 2012)
Pembelajaran fisika dasar menggunakan field trip, terlebih dahulu dilakukan pretes untuk mengetahui kemampuan mahasiswa terkait pemahaman konsep fisika dasar. Hasil pretes 55.71 dan postes 72.48 untuk kelas kontrol dengan $\mathrm{N}$-gain 0.38 (kategori sedang). Hasil pretes untuk kelas eksperimen 55.75 dan postes 80.35 dengan $\mathrm{N}$-gain 0.56 (kategori sedang). Diketahui $\mathrm{N}$-gain kelas eksperimen dan kontrol dalam kategori sedang.. Hasil pretes dan postes kelas eksperimen dan kontrol disajikan pada Tabel 3.

Tabel 3. Nilai Pretes-Postes Pemahaman Konsep Fisika

\begin{tabular}{lccc}
\hline \multicolumn{1}{c}{ Kelas } & Pretes & Postes & N-Gain \\
\hline Kontrol & 55.71 & 72.47 & 0,38 \\
Eksperimen & 55.75 & 80.35 & 0,56 \\
\hline
\end{tabular}

Hasil uji menunjukan kedua kelas homogen. Selanjutnya, dilakukan uji normalitas data hasil pretes dan postes dan N-gain. Hasil uji normalitas dapat dilihat pada Tabel 4 .

Tabel 4. Uji Normalitas Kemampuan Pemahaman Konsep Fisika

\begin{tabular}{|c|c|c|c|}
\hline \multicolumn{2}{|c|}{ Shapiro-Wilk } & \multirow{2}{*}{$\begin{array}{c}\begin{array}{c}\text { Value } \\
\text { of Sig. }\end{array} \\
0.031\end{array}$} & \multirow{2}{*}{\begin{tabular}{l}
\multicolumn{1}{c}{ Interpretas } \\
Tidak \\
terdistribusi \\
normal
\end{tabular}} \\
\hline Kontrol & Pretes & & \\
\hline & Postes & 0.052 & $\begin{array}{l}\text { Terdistribusi } \\
\text { normal }\end{array}$ \\
\hline \multirow[t]{2}{*}{ Eksperimen } & Pretes & 0.351 & $\begin{array}{l}\text { Terdistribusi } \\
\text { normal }\end{array}$ \\
\hline & Postes & 0.375 & $\begin{array}{l}\text { Terdistribusi } \\
\text { normal }\end{array}$ \\
\hline \multirow[t]{2}{*}{ Gain } & Kontrol & 0.061 & $\begin{array}{l}\text { Terdistribusi } \\
\text { normal }\end{array}$ \\
\hline & Eksperimen & 0.491 & $\begin{array}{l}\text { Terdistribusi } \\
\text { normal }\end{array}$ \\
\hline
\end{tabular}

Tabel 4 menunjukan bahwa nilai pretes kelas kontrol tidak terdistribusi normal. hal itu berdampak pada uji stastistik untuk menguji hipotesis penelitian. Karena terdapat data yang tidak terdistribusi normal, maka dilakukan uji statistik non parametrik. Uji Mann-Whitney dilakukan untuk menguji hipotesis. Uji hipotesis berdasarkan nilai tes dan N-Gain kemampuan penguasaan konsep fisika. Hasil uji hipotesis ditunjukkan Tabel 5. 
Tabel 5. Hasil Uji Hipotesis Penelitian

\begin{tabular}{ccl}
\hline $\begin{array}{c}\text { Mann- } \\
\text { Whitney } \\
\text { U }\end{array}$ & $\begin{array}{c}\text { Asymp. } \\
\text { Sig. (2- } \\
\text { tailed) }\end{array}$ & \multicolumn{1}{c}{ Interpretasi } \\
\hline Pretes & 0.884 & $\begin{array}{l}\text { tidak terdapat perbedaan } \\
\text { kemampuan awal antara } \\
\text { kelas eksperimen dan } \\
\text { kontrol } \\
\text { terdapat perbedaan } \\
\text { pemahaman konsep } \\
\text { kelas eksperimen dan } \\
\text { kontrol } \\
\text { terdapat perbedaan } \\
\text { peningkatan } \\
\text { pemahaman konsep } \\
\text { kelas eksperimen dan } \\
\text { kontrol }\end{array}$ \\
& 0.000 \\
& 0.002 & \\
& &
\end{tabular}

Tabel 5 menunjukan bahwa tidak ada perbedaan kemampuan pemahaman konsep antara kelas eksperimen dan kontrol. Hasil postes dan N-Gain menunjukan bahwa ada perbedaan kemampuan pemahaman konsep kelas eksperimen dan kelas kontrol. Berdasarkan hasil uji nilai $\mathrm{N}-$ Gain sangat signifikan. Data tersebut menunjukan bahwa pembelajaran fisika melalui filed trip meningkatkan kemampuan pemahaman konsep fisika secara signifikan.

Konsep fisika yang diujikan dalam kegiatan pembelajaran yaitu konsep gaya, usaha dan energi, magnet, listrik dan optik. Kemampuan pemahaman konsep fisika kelas eksperimen dapat disajikan dalam Gambar 1.

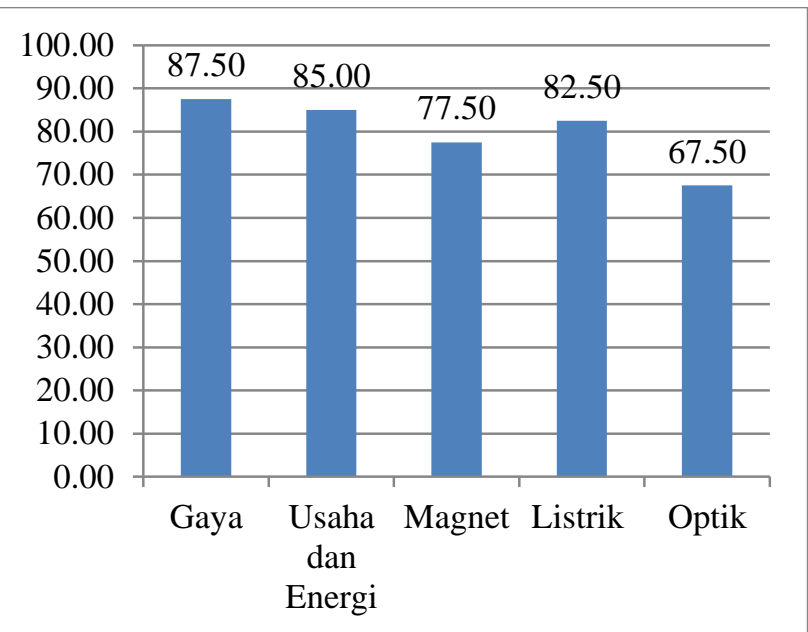

Gambar 1. Kemampuan Pemahaman Konsep Fisika Kelas Eksperimen

Kemampuan pemahaman konsep fisika kelas kontrol juga diukur sesuai materi yang digunakan dalam proses pembelajaran. Berikut disajikan Gambar 2 Kemampuan pemahaman konsep fisika kelas kontrol.

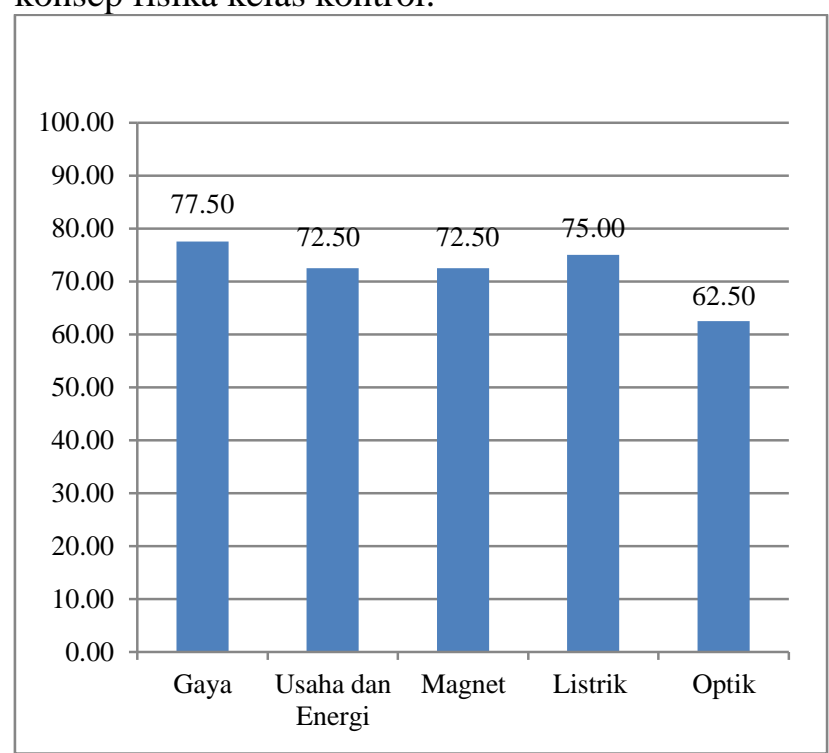

Gambar 2. Kemampuan Pemahaman Konsep Materi Fisika Kelas Kontrol

Kemampuan pemahaman konsep optik pada mahasiswa kelas eksperimen mempunyai nilai rata-rata paling kecil diantara konsep yang lain. Pemahaman konsep optik pada mahasiswa kelas kontrol mempunyai rata-rata yang paling rendah diantara konsep yang lain. Pemahaman konsep fisika kelas eksperimen lebih tinggi dari pada kelas kontrol untuk masing-masing konsep yang diujikan. Kemampuan pemahaman konsep fisika kelas eksperimen dan kontrol disajikan pada Gambar 3. 


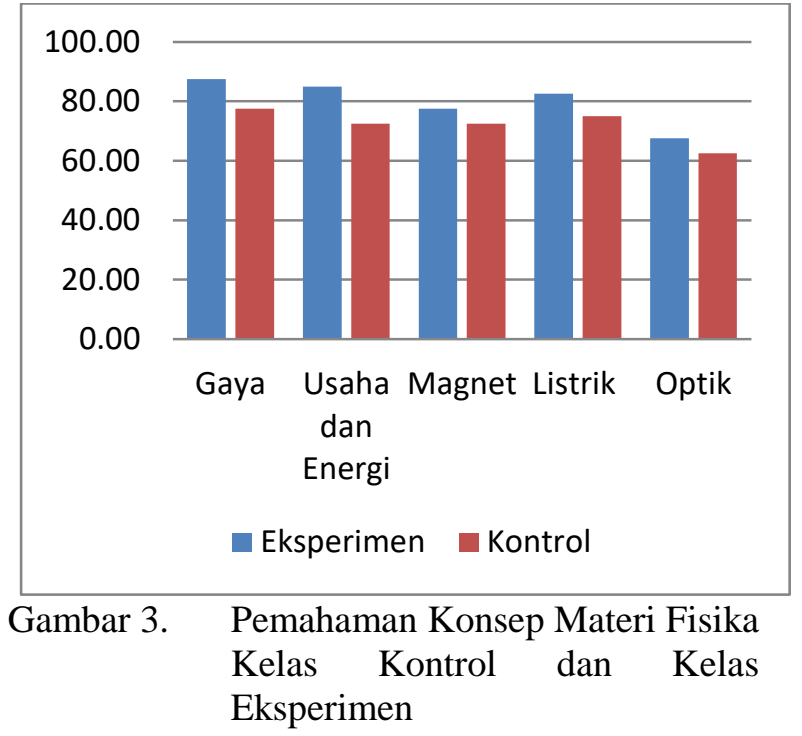

Keterampilan proses sains mahasiswa kelas eksperimen meliputi keterampilan dasar, keterampilan memroses dan keterampilan investigasi. Berikut keterampilan proses sains kelas eksperimen yang disajikan pada Tabel 6 .

\begin{tabular}{lll} 
Tabel 6. & $\begin{array}{l}\text { Keterampilan } \\
\text { Mahasiswa }\end{array}$ & Proses Sains \\
\hline
\end{tabular}

\begin{tabular}{llc}
\hline No & Keterampilan Proses Sains & $\begin{array}{c}\text { Rata- } \\
\text { Rata }\end{array}$ \\
\hline & Keterampilan Dasar & \\
1 & Pengamatan & 3.55 \\
2 & Mencatat data & 3.86 \\
3 & Mengikuti instruksi & 3.31 \\
4 & Melakukan pengukuran & 3.72 \\
5 & Melakukan manipulasi & 3.34 \\
6 & Mengimplementasikan prosedur & 3.86 \\
& Keterampilan Memroses & \\
7 & Membuat Prediksi & 3.72 \\
8 & Membuat inferensi & 3.86 \\
9 & Menyeleksi prosedur & 3.03 \\
& Keterampilan Investigasi & \\
10 & Merancang Investigasi & 3.55 \\
11 & Melaksanakan Investigasi & 3.55 \\
12 & Melaporkan hasil investigasi & 3.55 \\
& Jumlah & 42,93 \\
& Kategori & Baik \\
\hline
\end{tabular}

Indikator keterampilan proses sains yang diukur sebanyak 12 indikator. Keterampilan proses sains mahasiswa yang diajar dengan metode field trip mempunyai kategori baik. Keterampilan proses sains mahasiswa diukur berdasarkan apa yang mereka kerjakan. Aspek keterampilan uang muncul ketika melaksanakan field trip. Keterampilan proses sains untuk tingkat keterampilan dasar, mahasiswa melakukan pengamatan pada objek (alat peraga magnet, listrik, optik, usaha dan energi). Mahasiswa mengikuti instruksi yang tertera dalam setiap objek yang diamati. Kemudian mahasiswa mencatat data hasil pengukuran. Mahasiswa melakukan kegiatan eksperimen maupun demonstrasi berdasarkan prosedur sesuai dengan prosedur yang tertera pada alat. Siswa juga melakukan manipulasi terhadap objek. Kegiatan manipulasi terhadap objek dengan cara melakukan manipulasi variabelvariabel yang ada pada objek kegiatan manipulasi misalnya mengubah-ubah sudut, mengubah tegangan, mengubah beban, mengubah kecepatan gerakan magnet, mengubah ukuran magnet. Keterampilan proses sains tersebut dapat diamati dengan menggunakan lembar observasi keterampilan proses sains.

Keterampilan proses sains untuk tingkat memroses diamati melalui lembar kerja mahasiswa. Mahasiswa melakukan kegiatan memprediksi terhadap objek yang akan diamati. Kegiatan inferensi dilakukan oleh mahasiswa setelah melakukan eksperimen. Kegiatan merancang investigasi dilakukan oleh mahasiswa pada perkuliahan sebelum pelaksanaan field trip berlangsung. setelah kegiatan merancang investigasi, Mahasiswa melakukan investigasi secara kelompok. Setelah melakukan kegiatan investigasi, mahasiswa membuat laporan hasil investigasi. Penilaian terhadap hasil investigasi dilakukan melalui laporan investigasi.

Sriarunrasmee et al. (2015) menyatakan bahwa field trip dapat meningkatkan pemahaman konsep sains, proses inquiry, dan keterampilan berpikir kritis siswa. Hasil belajar dari field trip dapat mengakses kemampuan kognitif dan afektif siswa (Dewitt \& Storksdieck, 2008; Bell et al. (2009). Pendapat ini juga diperkuat dari temuan Kiesel (2005) yang menyatakan bahwa melalui kegiatan field trip dapat mengidentifikasi kemampuan kognitif siswa. Pembelajaran melalui field trip dapat membangun pengetahuan siswa tentang listrik dan magnet dengan memanfaatkan aspek pengalaman selama kunjungan sekolah ke museum sains. Anderson et al. (2000) memberikan bukti bahwa serangkaian kegiatan pasca kunjungan terpadu menghasilkan siswa membangun dan merekonstruksi pengetahuan 
pribadi mereka tentang konsep dan prinsip sains yang diwakili dalam pameran museum sains.

$$
\text { Demirkaya \& Atayeter (2011) }
$$

menyatakan bahwa field trip memberi pengalaman kepada mahasiswa dan dosen dalam pendekatan penelitian sebagai kegiatan eksperimental. Mahasiswa mendapatkan pengetahuan melalui pengalaman langsung. Hasil pembelajaran sains menggunakan field trip yaitu mahasiswa mendapatkan pengalaman baru dan dapat meningkatkan minat dan keterlibatan dalam sains tanpa mempedulikan minat sebelumnya pada suatu topik (Kisiel, 2005; Bonderup Dohn, 2011), keuntungan afektif seperti perasaan positif terhadap topik (Csikszentmihalyi \& Hermanson, 1995; Nadelson \& Jordan, 2012), pengalaman yang dapat diingat dan berguna lama setelah kunjungan (Salmi, 2003; Falk \& Dierking, 1997; Wolins, Jensen, \& Ulzheimer, 1992).

Keberhasilan kegiatan field trip tidak terlepas dari persiapan yang matang. Persiapan pra filed trip, pelaksanaan filed trip dan pasca filed trip. Field trip yang sukses dan berkualitas memerlukan persiapan dan interaksi antara mahasiswa dan dosen (Griffin \& Symington, 1997). Temuan Anderson et al. (2000) terkait pembelajaran melalui field trip yaitu ada keterkaitan antara pembelajaran yang terjadi di kelas, rumah dan museum sains. Pengajar dan staf museum sains merencanakan kegiatan pra dan pasca kunjungan. Pentingnya perencanaan dapat mendukung konsepsi ilmiah siswa, dan mendeteksi dan merespon konsepsi alternatif yang diproduksi atau diperkuat saat berkunjung ke museum sains

Orion \& Holfstein (1994) menjelaskan bahwa agar pembelajaran sukses maka kegiatan field trip harus dihubungkan dengan kurikulum kelas. Morentin \& Guisasola (2015) field trip ke pusat sains dianggap sebagai sumber belajar yang sangat baik mengingat potensi rekreasi dan pendidikan mahasiswa, namun kunjungan perlu diintegrasikan ke dalam program kelas untuk mengoptimalkan pembelajaran. NSTA (1999) menegaskan kunjungan lapangan dapat "memperdalam dan meningkatkan" pembelajaran di kelas, NRC (1996) menegaskan bahwa kurikulum sains berkualitas adalah bidang yang melampaui dinding kelas.

Orion, N., \& Holfstein, A., (1994) efektifitas field trip dikendalikan oleh dua faktor yaitu kualitas perjalanan lapangan dan kebaruan. Kualitas field trip ditentukan oleh struktur, bahan pelajaran, dan metode pengajaran dan kemampuan untuk langsung belajar menghadapi interaksi konkrit dengan lingkungan. Ruang kebaruan peserta didik terdiri dari tiga variabel sebelum filed trip yaitu, kognitif, psikologis dan geografis.

Temuan Yarid \& Ariswan (2016) terkait metode field trip dalam pembelajaran fisika yaitu kurangnya minat dari peserta didik selama proses tanya jawab guna menggali lebih detail informasi yang diperoleh, pengawasan dari tiap individu selama di lapangan dan perbedaan gaya belajar siswa. Temuan tersebut dapat diatasi dengan melakukan kerjasama antara dosen, asisten praktikum dan instruktur di Taman Pintar. Pendampingan kepada mahasiswa selama field trip di Taman Pintar. Kegiatan tanya jawab juga dilakukan ketika mahasiswa mendiskusikan hasil pengamatan. Antwi \& Oppong (2014) menyatakan bahwa field trip dapat menjadikan pembelajaran sains yang interaktif.

Pembelajaran fisika menggunakan metode field trip dapat mengakses kemampuan keterampilan proses sains mahasiswa. Pembelajaran fisika menggunakan metode field trip dapat meningkatkan pemahaman konsep fisika. Hal ini sejalan dengan temuan Ratnasari (2014) yang mengemukakan bahwa, metode field trip dalam pembelajaran menjadikan keterampilan proses sains dan konsep siswa lebih baik. Temuan Dewit \& Storksdieck (2008) juga menyatakan bahwa pembelajaran di luar kelas dapat mengasah kemampuan kognitif dan afektif siswa. Kemampuan kognitif yang diukur dalam penelitian berupa kemampuan pemahaman konsep fisika. Penelitian ini tidak mengukur kemampuan aspek afektif yang muncul dalam pembelajaran. Aspek afektif khususnya sikap ilmiah mahasiswa dalam kegiatan field trip perlu diukur.

Pembelajaran fisika menggunakan metode field trip mempunyai kendala yaitu yaitu adanya keterbatasan waktu, jarak, biaya, dan tingkat keamanan. Oleh karena itu, Çaliskan (2011) memberi alternatif dalam pembelajaran sains melalui field trip virtual untuk kunjungan lapangan aktual. Pembelajaran sains melalui virtual dapat menekan biaya, waktu dan keamanan. Kemajuan teknologi seperti smartphone maupun perangkat elektronik digital lainnya dapat digunakan mahasiswa untuk melakukan eksperimen, demonstrasi secara virtual tanpa takut atas kerusakan alat laboratorium. 


\section{Simpulan dan Saran}

Simpulan

Pembelajaran fisika dasar melalui metode field trip dapat meningkatkan kemampuan pemahaman konsep fisika dan dapat mengakses keterampilan proses sains mahasiswa. Kemampuan pemahaman konsep fisika kelas eksperimen terdapat perbedaan yang signifikan dibandingkan dengan kelas kontrol. Keterampilan proses sains yang dapat diakses melalui kegiatan field trip yaitu keterampilan dasar, keterampilan memroses dan keterampilan investigasi. Keterampilan dasar yang dominan yaitu mencatat data, melakukan pengukuran dan mengimplementasikan prosedur. Keterampilan memroses yang paling dominan yaitu membuat prediksi dan membuat inferensi.

\section{Saran}

Saran dari hasil penelitian memberikan rekomendasi bagi peneliti selanjutnya yaitu untuk mengatasi keterbatasan waktu dan biaya, maka diperlukan alternatif field trip dalam pembelajaran fisika dasar dengan menggunakan virtual field trip. Filed trip juga dapat dilakukan dengan mengamati fenomena alam yang ditemui mahasiswa dalam kehidupan seharihari. Selain laporan yang menjadi outcame dari kegiatan field trip, mahasiswa perlu dilatih menghasilkan artikel ilmiah dari hasil field trip. Aspek sikap ilmiah dalam proses field trip perlu diukur.

\section{Ucapan Terima Kasih}

Terimakasih kepada mahasiswa Tadris Biologi IAIN Syekh Nurjati Cirebon Semester 1 Tahun Akademik 2017/2018 yang telah berpartisipasi dalam kegiatan penelitian.

\section{Daftar Pustaka}

Amosa, A.G., Ogunlade, O.O., \& Atobatele, A.S. (2015). Effect of field trip on student academic performance in basic technology in Ilorin Metropolis, Nigeria. Malaysian Online Journal of Educational Technology, 3 (2): 1-6.

Anderson, D., Lucas, K. B. \& Ginns, I. S. (2000). Development of knowledge about electricity and magnetism during a visit to a science museum and related post-visit activities. Science Education, 84(5), 658-679.

Anderson, L.W. \& Krathwohl, D.R. (2001). A taxonomy for learning, teaching, and assessing: a revision of bloom's taxonomy of educational objectives. Abridged Edition. New York: Adisson Wesley Longman.

Antwi, V. \& Oppong, C. Snr. (2014). Using field trip ti promote anctive participation among pupils of mumford community jhs Ghana to improve their performance in science. Journal of Education and Curriculum Development Research, 2(4): 152-166.

Bell, P., Lewenstein, B., Shouse, A. W., \& Feder, M. A. (2009). Learning science in informal environments: People, places, and pursuits. (Ed) Washington, DC: National Academies Press. Retrieved.

Bonderup Dohn, N. (2011). Situational interest of high school students who visit an aquarium. Science Education, 95(2), 337-357.

Bryce, T. G. K., McCall, J., MacGregor, J., Robertson, I.J., and Weston, R. A. J. (1990). Techniques for assessing process skills in practical science: Teacher's guide. Oxford: Heinemann Educational Books.

Çaliskan, O. (2011). Virtual field trips in education of earth and environmental sciences. Procedia-Social and Behavioral Sciences, Vol 12: 32393243.

Carin \& Sund. (1990). Teaching science through discovery $\left(7^{\text {th }} e d\right.$.) New York: Merrill Publishing Company.

Collette, A. T. \& Chiappetta, E. L. (2007). Science instruction in the middle and secondary schools. New York: Macmillan.

Csikszentmihalyi, M., \& Hermanson, K. (1995). Intrinsic motivation in 
museums: Why does one want to learn? In J. H. Falk \& L. D. Dierking (Eds.), Public institutions for personal learning (pp.67-77). Washington DC: American Association of Museums. DOI: 10.1016/j.sbspro.2011.04.278

Demirkaya, H. \& Atayeter, Y. (2011). A study on the experiences of university lecturers and students in the geography field trip. Procedia-Social and Behavioral Sciences, 19: 453-461. DOI: 10.1016/j.sbspro.2011.05.154.

Dewit, J. \& Storksdieck, M. (2008). A short review of school field trips: Key findings form the past and implication for the future, Visitor Studies Association, 11(2), 181-197. DOI: $10.1080 / 10645570802355562$.

Dewitt, J. \& Osborne, J. (2007). Supporting teachers on science-focused school trips: Towards an integrated framework of theory and practice. International Journal of Science Education, 29, 685710.

Falk, J. \& Direking, L. (1997). School field trips: Assessing their long-term impact. Curator, 40, 211-218. DOI: $10.1111 / \mathrm{j} .2151-$ 6952.1997.tb01304.x/abstract

Fatkur, T. R. (2013). Peningkatan pembelajaran pelestarian alam melalui metode field trip siswa sekolah dasar. Journal of Elementary Education, 2(1): 29-35

Gardner, H. (1999). The dicipline mind: What all students should understand. New York: Simon \& Schuster Inc.

Japar, M. (2017). Efektivitas penggunaan model pembelajaran reciprocal teaching dengan melakukan field trip di PLTU Jeneponto terhadap hasil belajar fisika siswa kelas XI IPA 1 \& XI IPA 2 materi usaha \& energi. Skripsi. UIN Alaudin Makasar. Available online: repositori.uin-

alauddin.ac.id/3838/1/MUCHLIS\%20J APAR.pdf.

Kisiel, J. F. (2005). Understanding elementary teacher motivations for science fieldtrips. Science Education, 89(6), $936-955$.

Kisiel, J. (2006). More Than Lions and Tigers and Bears-Creating Meaningful Field trip Lesson. Science activities, 43 (2).

Lubis, I. S. (2009). Tingkatan pemahaman mahasiswa pada konsep fisika. Media Invotama 4(8):14-22.

Marini, R. M. \& Retnoningsih, A. (2016). Efektifitas metode field trip di sungai kaligarang semarang terhadap hasil belajar siswa materi pengelolaan lingkungan. Journal of Biology Education 5(1). Available online: https://journal.unnes.ac.id/artikel_sju/uj be/12472.

Meltzer, D. E. (2002). The relationship between mathematics preparation and conceptual learning gains in physics: A possible "hidden variable" in diagnostic pretest scores. American Journal of Physics, 70, 1259-1268.

Morentin, M. \& Guisasola, J. (2015) The Role Of Science Museum Field trips In The Primary Teacher Preparation. International Journal of Science and Mathematics Education, 13: 965-990. DOI: 10.1007/s10763-014-9522-4

Mundilarto \& Suharyanto. (2015). Pengembangan model outdoor learning untuk menumbuhkan sikap spiritual dan sosial melalui pembelajaran fisika. Yogyakarta: LPPM. Available online: http://eprints.uny.ac.id/36773/

Myers, B. \& Linda J. (2012). Effective use of field trip in educational programing: A Three Stage Approach. Florida: IFAS Extention University of Florida. Available online: http://edis.ifas.ufl.edu/wc054.

National Research Council. (1996). National Science Education Standards. Washington, DC: National Academies Press. Retrieved from http://www.nap.edu/openbook.ph p?record_id $=4962$

National Science Teachers Association (1999). NSTA Position Statement: Informal 
Science Education. Retrieved from http://informalscience.org/researc h/ic-000-000-009-

678/NSTA_Position_Statement

Omosewo, E. O. (2009). Formal instructional method (3): laboratory, demonstration and field trip methods on instruction. principle and practice of instruction. Ilorin Nigeria: Bamitex.

Orion, N., \& Holfstein, A., (1994). Factors that influence learning during a scientific field trip in a natural environment. Journal of Research in Science Teaching. $\quad$ DOI: 10.1002/tea.3660311005.

Patrick, A. O. (2010). Effect of field studies on learning outcome in biology. J.Hum. Ecol. 31(3): 171-177.

Patrick, P., C. Mathews. (2013). Using a field trip inventory to determine if listening to elementary school students' conversations, while on a zoo field trip, enhances preservic teachers' abilities to plan zoo field trips. International Journal of Science Education, 35(15), 2645-2669.

Pradyani, I.A.A.M., I Made S., \& I Made A. (2014). Penerapan metode field trip sebagai upaya meningkatkan katrampilan menulis karangan deskripsi siswa di Kelas VII A.3 SMP Negeri 1 Singaraja. E-journal Universitas Pendidikan Ganesha, 2(1):1-10

Prasetyo, A. (2015). Keefektifan Metode Field trip Terhadap Hasil Belajar Sumber Daya Alam Siswa Kelas III SDN Bagongan 1 Kabupaten Banyumas. Skripsi, Universitas Negeri Semarang. Available online: lib.unnes.ac.id/20264/1/1401411295s.pdf.

Rahayu, Y. (2013). The Influence Of Using The Ten Thousand Hills as a source of." Jurnal Gea 13(2):51-59. Available online:

(http://ejournal.upi.edu/index.php/gea/a rticle/view/3355/2351).
Ratnasari, D. (2014). Pengaruh pemanfaatan mangrove cagar alam pulau dua melalui Kegiatan field trip terhadap keterampilan proses sains dan sikap ilmiah siswa SMA pada konsep pencemaran lingkungan. Prociding Mathematics And Sciences Forum 2014.

Rochimah, Umi \& Akhdinirwanto, R.Wakhid. (2011). Penerapan field study untuk peningkatan aktivitas dan prestasi belajar fisika pada siswa kelas XI IPA Madrasah Aliyah An Nawawi Berjan Purworejo.” Pp. 291-300 in Seminar Nasional Penelitian, Pendidikan dan Penerapan MIPA.

Sakti, I. (2013). "Pengaruh media animasi fisika dalam model pembelajaran langsung (direct instruction) terhadap minat belajar dan pemahaman konsep fisika siswa di SMA Negeri Kota Bengkulu." Pp. 493-98 in Prosiding Semirata FMIPA Universitas Lampung, 2013.

Salmi, H. (2003). Science centres as learning laboratories: experiences of Heureka, the Finnish Science Centre. International Journal of Technology Management, 25, 460-476.

Sriarunrasmee, J., Suwannatthachote, P., \& Dachakupt,, P. (2015). Virtual Field trips with Inquiry learning and Critical Thinking Process: A Learning Model to Enhance Students' Science Learning Outcomes. Procedia-Social and Behavioral Sciences, $197: 1721-1726$. DOI: 10.1016/j.sbspro.2015.07.226.

Sukardjo. (2008). Penilaian Hasil Belajar Kimia. Yogyakarta: Program Pascasarjana Universitas Negeri Yogyakarta.

Suparno, P. (2007) Metodologi Pembelajaran Fisika Konstruktivistik dan Menyenangkan. Yogyakarta: Universitas Sanata Darma.

Ubaidillah, M. (2016). Pengembangan LKPD fisika berbasis problem solving untuk meningkatkan keterampilan proses sains dan keterampilan berpikir tinkat tinggi. EduFisika, 1(2): 9-20. 
Wolins, I. S., Jensen, N., \& Ulzheimer, R. (1992). Children's memories of museum field trips: A qualitative study. Journal of Museum Education, 17(2), $17-27$.

Yarid, H. \& Ariswan. (2016). Pengembangan Perangkat Pembelajaran Fisika Problem Based Learning Melalui Kegiatan Fieldtrip pada Materi Energi. Jurnal Inovasi Pembelajaran IPA, 2 (1), 2016, 24-34.

Yuliati, T., \& Martuti, N. K. (2014). Efektivitas penerapan metode field trip untuk meningkatkan hasil belajar dan kepedulian siswa terhadap lingkungan. Jurnal Matematika dan Sains 11(2):178-86. 